\title{
Adjetivación en crónicas de Abraham Valdelomar
}

\section{Adjectivation in Abraham Valdelomar's Chronicles}

\author{
María del Carmen Sala \\ Universidad Nacional Mayor de San Marcos, Lima, Perú \\ maria.sala@unmsm.edu.pe
}

\begin{abstract}
Resumen
Abraham Valdelomar es un artista que hace periodismo. Lo revela el lenguaje utilizado en sus crónicas y, especialmente, su forma de usar el adjetivo en ellas. El objetivo del presente artículo es mostrar los patrones de su manejo de la adjetivación para lo cual se analizaron cuatro crónicas. Pese a la diversidad de características encontradas, estos patrones parecen responder a una combinación de criterios: dar precisión a los hechos que se describen o narran y, a la vez, expresar una apreciación personal. Se percibe una doble tensión en el autor. Por una parte, el escritor debe cumplir con los requerimientos de un texto que se publica en un medio de comunicación cuyo principal fin es informativo, y por otra, desea manifestar sus puntos de vista y sus sentimientos con respecto a lo descrito o narrado. Este doble juego se resuelve en la cantidad y el tipo de adjetivos que utiliza.
\end{abstract}

Palabras clave: Valdelomar, crónica, adjetivo, modernismo.

\begin{abstract}
Abraham Valdelomar is a renowned writer who also makes journalism. This is evident in the language he used in his chronicles, particularly, in the usage of adjectives. In this paper, four of his chronicles were analized in order to show the patterns of his handling of adjectives. These patterns can be directly linked to two criteria: to specify the described or narrated events and to provide a personal appreciation of them. A double tension is perceived in the author. As a journalist he had to comply with the requirements of a media text whose main purpose is to inform, on the other hand, as a writer he wanted to express his views and feelings regarding what had been described or narrated. This double purpose is resolved in the amount and type of adjectives he uses.
\end{abstract}

Keywords: Valdelomar, chronicle, adjective, modernism. 


\section{María del Carmen Sala}

\section{Introducción}

El presente trabajo fija su atención en la manera como Abraham Valdelomar utiliza adjetivos en sus crónicas con el fin de determinar si el uso responde a criterios literarios y no meramente informativos. Esta interrogante se plantea luego de que una estudiosa de las crónicas de Valdelomar, Esther Espinoza (2007), sostuviera que «han surgido dudas acerca de su literariedad» (p. 9). Para contribuir a despejar esas dudas, se analizarán cuatro crónicas, seleccionadas por referirse a muy distintos espacios vitales del autor.

Las primeras prosas de Abraham Valdelomar fueron doce crónicas publicadas bajo el título «Con la argelina al viento». Entre ellas, está «El rey muerto», una de las crónicas seleccionadas como representativa de lo escrito por Valdelomar en 1910. Tres años más tarde escribe «Desde Roma» en la capital italiana, texto que forma parte de las denominadas «Crónicas de Roma» y que fue publicado en $L a$ Nación. El 10 de octubre de 1916 publica en el diario La Prensa el texto titulado «Dando el opio...», un buen ejemplo de la labor desempeñada por Valdelomar como cronista parlamentario. En ese mismo diario, publica al mes siguiente, «La primera hoja seca...» en la columna «Fuegos fatuos», firmándola con el seudónimo El Conde de Lemos.

¿Por qué enfocarse en el análisis de la adjetivación? No existe consenso sobre qué determina la calidad artística de un texto narrativo ni sobre el papel de la adjetivación para diferenciar si en él prima el afán informativo o la búsqueda de la belleza. Cabe probar si la adjetivación es un buen indicador pues, como dijo Azorín, «la literatura está en el adjetivo».

Una primera parte de este texto incluye un breve marco teórico que contiene explicaciones básicas sobre el adjetivo, poniendo énfasis en una diferencia semántica (objetivo / subjetivo) y otra sintáctica (antepuesto / pospuesto). Incluye, además, un recuento de los vínculos que mantiene la crónica con la historia y la literatura, y de la importancia que tuvo la crónica en el movimiento modernista. También se hace un repaso de las características atribuidas a la adjetivación modernista, para terminar con referencias a la obra de Valdelomar.

Después del marco teórico, se explica la metodología utilizada para el análisis y se entra en el análisis de cada una de las cuatro crónicas. Finalmente, se esbozan conclusiones y en ellas se plantea una ruta por donde podría continuarse el estudio de los adjetivos en las crónicas de Valdelomar. 


\section{Marco teórico}

\subsection{El adjetivo}

Según el Diccionario de la Real Academia Española (DRAE), adjetivo es la «clase de palabras cuyos elementos modifican a un sustantivo o se predican de él, y denotan cualidades, propiedades y relaciones de diversa naturaleza». Para la Nueva gramática básica de la lengua española, es el núcleo de un sintagma adjetival (también llamado grupo adjetival o frase adjetival), una construcción sintáctica que contrae funciones de modificador nominal y de atributo en todas sus variedades. El adjetivo puede recibir modificadores y complementos, añade.

La adjetivación — entendida como el empleo del adjetivo — es considerada una figura retórica, por lo que la norma periodística la recomienda para espacios dedicados a la opinión y la interpretación. Quienes ejercen el periodismo noticioso deben usar los adjetivos con moderación y, en aras de una pretendida objetividad, solo cuando lo exige la descripción o narración de un hecho. El profesor de redacción uruguayo Martín Acuña (2012) señala: «¿Cuándo es necesario adjetivar en un artículo periodístico? La respuesta es sencilla, cuando realmente ese adjetivo es importante a efectos de informar.»

Un escritor necesita recurrir al adjetivo para calificar la realidad que describe, y el adjetivo calificativo expresa una cualidad y aporta un valor significativo a la obra: brinda información, refleja una apreciación, trasmite emociones de los protagonistas y/o del narrador, sirve para crear atmósferas, da ritmo y fuerza a un texto y lo embellece. Sin embargo, algunos escritores, críticos y estudiosos piensan que es preferible ayudar a que el lector elabore sus propias imágenes mentales, que «vea» al personaje en acción, en vez de darle a conocer únicamente la característica que se le atribuye. Para ellos, afirmar que un personaje es malo (usando un adjetivo calificativo) es menos efectivo que presentarlo realizando una acción que refleje esa maldad (usando un verbo). Los verbos cuentan la historia; los adjetivos, le dan un marco, un tono, un complemento.

El escritor y editor Alberto Marcos (2015, 17 de marzo) recuerda la diferencia entre lo denotativo y lo connotativo: si usamos adjetivos y descripciones de forma connotativa, estaremos sugiriendo; en cambio, si explicamos claramente lo que siente el personaje en una escena, lo que hacemos es informar o explicar. Añade que cada escena, cada momento de una obra debe transmitir una sensación concreta 


\section{María del Carmen Sala}

y que, según lo que se quiera, se opta por un campo semántico determinado. De acuerdo a esta decisión, se seleccionan y combinan los adjetivos calificativos.

La diferencia entre lo denotativo y lo connotativo será considera en este trabajo al momento de distinguir el adjetivo que acá denominaremos «objetivo» del «subjetivo». El objetivo es aquel que se refiere a alguna característica verificable por cualquier persona; mientras el subjetivo es el que expresa apreciaciones personales y en ocasiones carga algún tipo de impertinencia. A esta diferencia semántica se suma una sintáctica que depende de la ubicación del adjetivo.

La editora y profesora española Carmen Javaloyes (2011) recuerda que «en el español hay un orden lógico según el cual el complementado precede al complemento: sustantivo + adjetivo, y toda alteración de ese orden se percibe como una desviación de tipo estilístico». Javaloyes (2011) añade que la adjetivación en literatura es el arte de intensificar la expresión y que la posición del adjetivo indica ya de por sí matices de significado.

El adjetivo antepuesto al sustantivo es de tipo explicativo, insiste en una de las cualidades del sustantivo, precisando y concretando su significado: refrescante bebida (de las muchas cualidades que posee esa bebida -dulce, cítrica, de determinado color...- se hace referencia sólo a una de ellas). Así, el adjetivo antepuesto matiza una de las características -de las muchas que posee un nombre- mientras que si está pospuesto esta característica no es esencial sino «accidental».

Javaloyes menciona a Hansseny Lenz para señalar que, desde el punto de vista psicológico, «el adjetivo antepuesto indica un carácter subjetivo, ya sea moral o estético, y el pospuesto un carácter objetivo de tipo lógico».

La adjetivación, además de ser en sí misma una figura retórica, permite construir otras figuras retóricas como la metáfora, la sinestesia, la hipálage, el oxímoron y muchas otras más.

\subsection{La crónica}

El término «crónica» fue acuñado en la Antigüedad — se hicieron crónicas de las conquistas romanas - y luego utilizado en la Edad Media para referirse a escritos de la Iglesia destinados a asentar acontecimientos notables. Hacia el siglo XVI, las crónicas ya estaban desapareciendo, reemplazadas por narraciones históricas como los cantares de gesta, y vuelven revitalizadas tras el descubrimiento y durante la conquista de América.

\section{$54 \quad$ Lengua \& Sociedad}


Para distinguir crónica de historia, se ha recurrido a múltiples criterios. Según el historiador y filósofo italiano Benedetto Croce (citado por Matute, 1997), la crónica se ocupa de los hechos individuales y privados, mientras la historia, de los generales y públicos. Otros han sostenido que la crónica es el primer nivel de conceptualización de un trabajo histórico y, a diferencia del relato, no tiene inicio ni final. Estas características no se pueden generalizar, pues la crónica se ha extendido, diversificado y evolucionado.

Los vínculos entre crónica e historia han sido menos polémicos que los vínculos entre crónica y literatura. El historiador mejicano Álvaro Matute (1997) recuerda que crónica es un vocablo con dos acepciones: una referida a la historiografía y la otra, al periodismo narrativo. «En la primera, hay crónica que sí es historia y en la segunda, crónica que sí es literatura» (p. 721). Esta postura tiene el mérito de no caer en generalizaciones - una crónica puede tener mayor o menor valor histórico, mayor o menor valor literario-, pero establece límites entre dos ámbitos -historia y literatura- que muchas veces son difusos.

El pasado es un caos, repleto de datos, documentos, anécdotas, pareceres, pasiones y cosas olvidadas ahora que serán esenciales más adelante. (...) La historia intenta ordenar ese caos. Una parte de la tarea historiográfica consiste en buscar y verificar datos usando criterios que podrían llamarse científicos. Pero otra parte de esta tarea es hacer una narración; identificar a protagonistas y antagonistas, establecer causas y efectos, asignar motivos, privilegiar algún dato sobre otros, generalizar, juzgar, nombrar y olvidar. (Shumway, 1992, pp. 8-9)

Actualmente nadie duda que las fronteras entre ficción y realidad no son nítidas y, por tanto, ya no se puede negar el carácter literario de una crónica argumentando que pretende dar testimonio de hechos reales. El escritor mejicano Carlos Monsiváis sostiene que el cronista trabaja desplazando los hechos, alterándolos, haciendo mutar el sentido de lo ocurrido (Tabarovsky, 2014), mientras su compatriota Elena Poniatowska plantea que es necesario considerar a la literatura testimonial como género literario (Gómez, 2001).

\subsection{La crónica modernista}

En Crónicas de la impaciencia: el periodismo de Alejo Carpentier, se sostiene que el estudio de la crónica como género y como estrategia narrativa resulta obligado para comprender la magnitud de un movimiento emblemático en la 


\section{María del Carmen Sala}

cultura hispanoamericana: el modernismo. (Cancio, 2010). La importancia de la crónica en el modernismo es corroborada por Susana Rotker cuando recuerda que a finales del siglo XIX se produce en nuestro continente una redefinición de la escritura periodística y literaria, encabezada por José Martí como corresponsal en New York de los diarios La Opinión Nacional, de Caracas (entre 1881 y 1882), y La Nación, de Buenos Aires (1882-1895). «La transformación de la escritura -y por ende de los modos de percepción de la realidad- fue de tal importancia que el periodismo se convirtió, así, en el vehículo de los primeros textos verdaderamente propios en América Latina» (Rotker, 1992a, p. 9).

José Martí y Manuel Gutiérrez Nájera (El Nacional de México, 1880) son los precursores de una transformación de la crónica, que se convierte en un punto de encuentro entre el discurso literario y el periodístico (Rotker, 1992b). La experiencia periodística se vuelve una constante entre los escritores modernistas y las crónicas que ellos producen - pese a haber sido desdeñadas por la críticaresultan fundamentales para comprender la estética del movimiento.

Luis Alberto Sánchez, citado por Espinoza (2007) «hace notar que la experimentación con diversidad de géneros es resaltante dentro del modernismo, pero afirma que la crónica es el género más 'inequívocamente trabajado y logrado por los modernistas'» (p. 58).

\subsection{Adjetivación modernista}

El escritor mejicano José Emilio Pacheco sostuvo que la estética que se encuentra al inicio del modernismo (la década de 1880) no es la misma que la de su etapa final, durante el segundo decenio del siglo xx. Pacheco añade que, a pesar de la diversidad del modernismo, mucho de su evolución puede palparse en el adjetivo.

En medio de la diversidad de características atribuidas al modernismo - o a los modernismos - se encuentran algunas constantes. Con respecto al adjetivo, podría afirmarse que hay consenso en que el modernismo suele utilizar gran cantidad de adjetivos y que estos pueden ser rebuscados y/o vinculados a los sentidos.

Para comprender el papel particular del adjetivo durante las distintas etapas del modernismo, resulta útil un estudio publicado con el título Tres momentos del adjetivo en la poesía modernista: Manuel Gutiérrez Nájera, Rubén Darío y Leopoldo Lugones. Su autor, el nicaragüense Roberto Carlos Pérez, señala lo siguiente:

El modernismo debilita la relación gramatical entre el sustantivo y el adjetivo al unirlos sin considerar su pertinencia «normal» $\mathrm{O}$ «normativa», descrita 
en los diccionarios y presente en la prosa de la época. (...) Aunque la impertinencia - término tomado de Jean Cohen en su estudio Estructura del lenguaje poético - siempre ha existido en la poesía, es el modernismo la estética que la exacerba y naturaliza, abriendo el camino a las insólitas imágenes poéticas que se desarrollarán poco después en la poesía vanguardista. (Pérez, 2017, p.9)

En la etapa inicial del modernismo, la impertinencia se hace evidente en las metáforas $y$, en especial, en la sinestesia, recurso que se presenta cuando son vinculados estímulos sensoriales de forma inusual, irracional, subjetiva, ilógica; en suma, impertinente. Las más frecuentes son las sinestesias generadas por la atribución de color a una experiencia incolora. En el caso de Rubén Darío, por ejemplo, su color predominante es el blanco, al que se refiere directamente o indirectamente con términos como pálido o nevado.

Con los modernistas, la sinestesia dio sus primeros pasos en Hispanoamérica y el adjetivo se vuelve imprescindible para crear imágenes llenas de color y movimiento. En pleno auge del modernismo, su estética asume como propios o característicos muchos adjetivos cuya novedad reside tanto en la importancia concedida a la sinestesia, como en la capacidad del adjetivo para transformarse en símbolo y, en menor escala, pero de gran importancia en la poesía, para modificarse morfológicamente o modificar formas verbales (Pérez, 2017).

Pérez explica que el tercer momento del modernismo construye el terreno poético propicio para el desarrollo de la vanguardia. Sostiene que ambos movimientos coexisten durante la segunda década del siglo xx en Hispanoamérica, pero que «es obra del modernismo el esfuerzo por hacer del adjetivo un elemento fundamental en la creación de metáforas y, por lo tanto, la forja de 'sentidos'» (Pérez, 2017, p. 3).

El papel de la adjetivación en el modernismo también ha sido estudiado por Edmundo García-Girón, profesor de la Universidad de Oregon (Estados Unidos). En el artículo ya mencionado, «La azul sonrisa. Disquisición sobre la adjetivación modernista», analiza poesías de dos poetas representativos del romanticismo (Espronceda) y del modernismo (Darío), utilizando el adjetivo como clave diferenciadora. En el artículo se señala que Darío utiliza mayor cantidad de adjetivos y que estos no pueden ser suprimidos porque crean efectos poéticos. Asimismo, asegura que la poesía modernista usa más adjetivos que la romántica y señala que esto revela su afición por la ornamentación y por lo externo. «La misma razón que explica la ornamentación de la poesía barroca explica la plétora adjetival del modernismo: el anhelo por expresar todos los matices posibles de la sensación» 


\section{María del Carmen Sala}

(García-Girón, 1955, pp. 101-112). García-Girón también sostiene que el adjetivo, en el modernismo, tiene mayor precisión poética.

El modernismo busca nuevos moldes para expresar su nueva sensibilidad. ¿Cómo logra este propósito? Devolviendo a la palabra aislada su valor intrínseco al subrayar su plurivalencia, sus matices y sus elementos acústicos; ensanchando el cauce sensorio de la palabra por medio de la sinestesia, el colorido simbólico y la metagoge; aumentando el caudal léxico por medio de invenciones (neologismos), restauraciones (arcaísmos, etimologismos) y préstamos (extranjerismos). (García-Girón, 1955, pp. 103-114)

Entre todos los elementos del lenguaje, García-Girón considera que el más interesante es el adjetivo debido a «su carácter subjetivo y estimativo (abstrae, humaniza, valoriza) y por sus fluctuaciones de una época a otra» (García-Girón, 1955, p. 98). El estudio de García-Girón concluye que nada explica mejor una época poética que la historia de sus adjetivos característicos, y por eso se puede distinguir el adjetivo clásico, romántico, modernista y postmodernista. «Los valores poéticos del adjetivo pueden surgir del adjetivo mismo, de una asociación de sustantivo y adjetivo, de su anteposición o postposición, etc., pero sea cual fuere su valor, el adjetivo es indudablemente uno de los mejores guías para penetrar en la selva de la poesía» (García-Girón, 1955, pp. 98 y 99).

Así como se puede penetrar en la selva de la poesía de la mano del adjetivo, es posible intentarlo en los accidentados terrenos de la crónica.

\subsection{Crónica y adjetivación en la obra de Valdelomar}

Los críticos ubican distintas influencias y tendencias en la obra de Abraham Valdelomar que incluyen decadentismo, D’Annunzio, Verlaine, Oscar Wilde y mucho más. Su poesía evoluciona del modernismo al postmodernismo, teniendo incluso atisbos de vanguardismo. En lo que se refiere a la crónica, el crítico literario y docente universitario Marcel Velázquez (2013) señala lo siguiente:

Valdelomar renueva la crónica. La crónica modernista es una crónica que emplea todos los recursos expresivos del modernismo: la plasticidad del lenguaje, la musicalidad de la frase, las frases breves y concisas e impactantes, en la línea de Óscar Wilde, una figura a la que admiraba Valdelomar. También Gabriel D'Anunzzio, un italiano. En ese campo hay un aporte decisivo de Valdelomar. Él hace muchos reportajes, incluso inventa reportajes. 
Luis Alberto Sánchez (1987) sostiene que el escritor iqueño «en concordancia con su celo imaginativo y temperamental, no concede tanto interés a la información como a los efectos publicitarios» (p. 161). El intelectual plantea que Valdelomar fue esencialmente un poeta, en verso y prosa (p. 162). Una opinión distinta tiene el poeta, editor y crítico literario Ricardo Silva Santisteban (2013):

Valdelomar es lo que se llama un narrador nato y, en mi concepto, no solo es el verdadero creador del cuento peruano y el más destacado de los escritores modernistas del Perú, sino también uno de los más grandes cuentistas del país (si no el más grande e importante) sobre todo por el aire de originalidad que se respira en sus cuentos, su variedad, su habilidad para la conducción de los eventos narrativos y por las excelencias de su estilo.

El investigador Sergio Ramírez Franco analizó seis cuentos de Valdelomar de los denominados «criollos» 0 «costeños»: «El caballero Carmelo», «El vuelo de los cóndores», «Yerba Santa», «Los ojos de Judas», «El buque negro»y «Hebaristo, el sauce que murió de amor». Ramírez (1992) concluyó que la muerte es el motivo principal de la obra de Valdelomar.

Ahora sabemos bien que la muerte es el verdadero eje de la fabulación de Valdelomar. Que su evocación nostálgica de la infancia conlleva, como reverso de la medalla, la obsesión tanática. Sabemos que no resulta casual, pues se repite en todos los textos costeños y en muchas otras obras suyas; pero que sea ahí donde su talento ha brillado como fuerza donde el tema se vuelva exclusivo, es un factor que nadie parece haber sopesado con el cuidado debido. Ante esto, no queda muy en pie la imagen que nos da Loayza, pues qué autor se ha mostrado tan monotemático como Valdelomar, cuya ligereza y buen humor se opone a la angustia, cuando sus textos más relevantes son la angustia misma. Pero hay más de una retórica de la angustia. Las hay paroxísticas, las hay desesperanzadas y pesimistas; pero en Valdelomar la angustia no impide el gozo de la sensualidad, la acrecienta... (pp. 129 y 130)

Sergio Ramírez Franco da una nueva interpretación a lo que llama «evocación nostálgica de la infancia» atribuida a Valdelomar por críticos como Luis Alberto Sánchez (1987): «La persistente imagen de la infancia reaparecerá una y otra vez en la obra literaria de Valdelomar. Como su tierra, ella será dulce, luminosa, tierna, sencilla, hecha de campo, mar, sol y de melancolía» (p. 26). Ramírez también vincula la angustia al goce de la sensualidad y las palabras del propio Valdelomar - al presentar un libro de poemas de Alberto Hidalgo- confirman el peso que 


\section{María del Carmen Sala}

le da a los sentidos: «El arte es la Naturaleza vista a través de un espíritu. Mejor aún, el arte es un instante de la Naturaleza a través de un estado de alma; aún más: un instante de infinito plasmado en una sensación».

El estudio de los adjetivos en el modernismo ha estado básicamente enfocado en la poesía. En el cuento, en el Perú, el lingüista y docente universitario Marco Lovón (2018) ha estudiado el empleo de adjetivos «El caballero Carmelo», el cuento más conocido de Abraham Valdelomar.

En este cuento, los gallos son definidos o representados por cualidades positivas y negativas poseídas o atribuidas. El protagonista, el Carmelo, es el gallo que recibe mayores adjetivaciones, sobre todo apreciativas, tales como caballeroso, musculoso y vencedor. Los adjetivos peyorativos están en relación a la vejez y la contienda gallística.

Las crónicas escritas por Abraham Valdelomar han sido poco analizadas y apreciadas. Una de sus estudiosas, Esther Espinoza (2007), señala que «la crítica ha excluido sistemáticamente del análisis literario de la obra de Valdelomar a sus escritos periodísticos» (p. 79). Es una tarea pendiente revisar la adjetivación en los relatos no ficcionales de Valdelomar para determinar cuál es su aporte en la literariedad de una obra y para avanzar en la comprensión de los recursos literarios que empleó al ejercer el periodismo.

\section{Metodología}

Para realizar el presente trabajo, se eligieron cuatro crónicas de Abraham Valdelomar y cada una de ellas fue analizada de la siguiente manera:

- Se dividió la crónica en segmentos. El criterio de la segmentación fue separar unidades de sentido, no párrafos, diferenciando dichas unidades por la predominancia de la descripción o de la narración. A cada segmento se le asignó un breve título.

- En cada segmento, se identificaron y contabilizaron los adjetivos. La adjetivación abundante es considerada un rasgo característico del modernismo.

- Se clasificaron los adjetivos, diferenciándolos en objetivos (escritos en tipo de letra regular) y subjetivos (en cursivas). Los objetivos se asocian a la redacción periodística y los subjetivos a la escritura literaria.

$60 \quad$ Lengua \& Sociedad 
Los sintagmas nominales se distinguieron gráficamente mediante el subrayado.

- Se sistematizó la estructura sintagmática utilizada al redactar los adjetivos; es decir, la manera en que fueron distribuidos y ubicados.

\section{Análisis}

\subsection{El rey muerto}

Firmada: Abraham Valdelomar. Soldado de Artillería.

Publicada: El Diario, 13 de mayo de 1910, p. 2.

\subsubsection{Resumen}

En esta crónica, Abraham Valdelomar narra distintos momentos de su vida en la Escuela Militar de Chorrillos, donde estuvo acuartelado luego de alistarse como soldado de la Reserva del Ejército en el año 1910, cuando estuvo a punto de estallar un conflicto bélico con Ecuador. Empieza esta crónica refiriéndose a un rey británico fallecido, tal como se lo describe a un compañero apellidado Villasana. A lo largo de cuatro párrafos, evoca diversas actividades públicas - protocolares y recreativas - del monarca. Luego de describir a su compañero Villasana y las guedejas, narra un ejercicio militar y un episodio frustrante con el diputado Franco. Finaliza la crónica dando a conocer el entusiasmo con el que enfrentaba los ejercicios de tiro al blanco.

\section{Evocación del rey}

-Serenamente irá hacia su recuerdo la oración de mis carillas, marchitas como las hermosas flores de Hyde Park, que melancolizaba el monarca espléndido en sus horas de correctísimo spleen.

¡El Rey! Cuando iba, Señor del imperio y de la moda a través de los vallados londinenses de los hipódromos que ennoblecían su presencia y alegraban su sonrisa, la suave sonrisa de sus ojos de rey.

Y las horas del palacio de Windsor y sus ceremonias en la abadía de Westminster donde oraban los reyes abuelos y las reinas de los cuadros de Van Dyck, y los paseos en los bosques y sus five o'clock en las terrazas de sus 


\section{María del Carmen Sala}

palacios. Sus salones bohemios en los que se confundían nobles y artistas, príncipes y pintores, pergaminos y paletas. Y la majestuosa sesión de su capa roja con lágrimas de armiño. Y su corona de oro en la que reían piedras de África y luces de rayos de sol.

La satisfacción de su sonrisa cuando triunfaban sus horses en Longchamps. Sus paseos en los salones de pintura y sus noches del Molino Rojo, con la distinción de su monocle y la espiritualidad de sus crisantemos o sus rosas de Francia...Todo esto le evocaba a mi compañero Villasana, el domingo mientras ciñéndome la cartuchera -insignia de cuartelero-, sufría la muerte de Rey artista.

\section{Descripción de compañero Villasana}

Todo esto le evocaba a mi compañero Villasana, el domingo mientras ciñéndome la cartuchera -insignia de cuartelero-, sufría la muerte de Rey artista. Pero este César Villasana no es para cosas tristes. Es un artillero deliciosamente piquichón, cuyo talento de apuntador es más discutible que sus chistes. Villasana es más que una pandereta o un par de castañuelas, una importación de Pérez Zúñiga, depilada y riente.

A Villasana le pasan las cosas más malas de la Batería. A él le dan las polacas más angostas. A él se le escapan los mulos y cuando en una acción de guerra cae algún prisionero, de seguro es Villasana.

\section{Descripción de guedejas}

Sin embargo, en medio del prosaísmo del cuartel hay notas de un sentimentalismo puro y emocionante. En un rincón del Caballerizo duermen religiosamente su olvido las guedejas de los patriotas, ilustres, nobles y plebeyos, que aquí pernoctan. Sobre los cabellos rebeldes y enérgicos de un buen soldado coronguino, descansa - ¡Oh triunfo de las democracias!- la guedeja cosmetizada y sentimental de un poeta trigueño. Las hay desde el rubio oro de sol hasta el negro azabache, y desde el rojo violento hasta el marrón muriente, cultivado en Huacachina o en los frascos de agua oxige nada. Y allí dormirán, hasta que las brisas frescas del mar, con engañosas 
caricias, las disperse y vuelvan a unirse con sus poseedores, poetas, horteras, aristócratas y plebeyos, en el valle eterno, y nos cuenten las incidencias de sus viajes dudosos, llevados con brazos del buen viento acariciador y refrescante. Rafael Kirchner, el dibujante filósofo de las cabelleras, habría sacado de aquí buenos modelos.

\section{Descripción de guedejas}

El ejercicio en campaña del martes ha sido el más interesante hasta hoy. El plan al que obedeció la campaña fue el siguiente: una batería de artillería debía salir de Chorrillos en dirección a Lurín, al mando del Teniente Romero, al mismo tiempo que fuerzas invasoras de las tres armas debían atacarla y apoderarse de sus cañones. La artillería de estas fuerzas estaba a cargo del Teniente Llona y se emplazó en el cerro de Santa Teresa, y la infantería, al mando del Alvérez Lagos, dividida en tres secciones que atacó a la altura de Villa.

La parte más interesante de esta lucha fue el ataque, por sorpresa, a la batería A del Teniente Romero, por las fuerzas C del Alférez Lagos. La batería A que se desempeñó admirablemente, burló la vigilancia del Cerro de Santa Teresa-Batería B, Teniente Llona- y sólo fue sorprendida al desfilar al frente de la hacienda Villa. Las secciones D y E, de infantería, tomaron posiciones a derecha e izquierda del camino del enemigo, pero fueron sorprendidas y tomadas prisioneras por los exploradores de la batería A, quedando toda la responsabilidad de combate a la sección F, que debía actuar por sorpresa, situándose en el paso obligado de la batería A.

Nada puede compararse en entusiasmo a esta clase de maniobras. Los combates simulados llegan a tener similitudes de verdaderos. Los exploradores actúan admirablemente y los prisioneros tomados son verdaderos triunfos.

Tomadas las posiciones llega el momento de la espera del enemigo. Es imposible contener la nerviosidad que se apodera de los soldados. Todos con los segundosqueparecen siglos. Elcentinela delaSección, Federico Vásquez, observa desde un árbol de 8 metros más o menos. Nadie se mueve y todos observan conteniendo casi la respiración, cuando de improviso la voz de él anuncia:

-jEI enemigo! ... 
La reacción inmediata. Los soldados adquieren cierta gravedad y sus movimientos revelan una impaciencia. Todos se preparan para el gran momento, se va a entrar al combate, se va a luchar y a vencer, se va a morir tal vez. El corazón marcha aceleradamente y las manos presionan con dureza las carabinas. El Alférez se alarga como un tigre entre los matorrales y de pronto envía su voz bajo y enérgica, en una orden:

-¡A la carga!

Los soldados adquieren vibraciones increíbles. Locos, furiosos, casi salvajes, se lanzan en tropel hacia el enemigo incauto que pasa por el camino. El fragor del combate los enardece más aún y en un empuje insostenible ante el enemigo estallan fuerzas inconocidas con un grito ronco, viril y dominante:

-¡Viva el Perú!

Luego la lucha sorda de cuerpo a cuerpo, los muertos, y la victoria. Esta vez hemos triunfado! ... Yo llegué a sugestionarme tanto en este combate simulado que lanzando la leyenda a todo pulmón, con mi carabina que apuntaba el enemigo, avancé hasta sus cañones, maté teóricamente a no sé que tantos de ellos; pero uno se resistió a darme su carabina y entonces, furiosamente, con la heroicidad de un valiente, le planté una bofetada tan llena de patriotismo, que le dejé medio rostro del color de la bandera.

[Qué lástima que este combate no haya sido verdadero!...

\section{Pequeño fracaso ante diputado Franco}

Al honorable señor Franco, debo, sin duda alguna, uno de mis pequeños fracasos. En la visita que este caballero hizo al cuartel el martes último, fui yo el designado para mostrarle el armamento Canet y darle una ligera idea de su funcionamiento. Satisfecho me froté las manos, adopté una de las poses habituales al alto comando, tosí 2 ó 3 veces y principié a iniciar al distinguido representante en los misterios del terrible explosivo Schneider, le hablé del tiro cegador, de la alza única y de la puntería indirecta. De los asaltos de la caballería y del ángulo de situación. Del siegue y de la teoría del milésimo y al concluir, tranquilo ya de mis dotes de orador y de artillero, cuando creí que el Señor Franco, contento y admirado, hablaría de mí en el Congreso, vi vagar con su cara bondadosa de Nazareno una sonrisa muy discutible.

\section{$64 \quad$ Lengua \& Sociedad}


Desgraciado de mí, el señor Franco sabía más que yo del armamento Canet, del armamento Krupp y de todos los armamentos. Había sido, además, antiguo alumno de la Escuela. Y yo le había estado relatando cuentos viejos. ¡Y que no sepa uno ciertas cosas antes de meterse a instruir a los diputados! Decididamente, esos señores se lo saben todo...

\section{Ejercicios de tiro al blanco}

Algo hay, antes de concluir estas carillas, que tiene humos de combate. Los ejercicios de fuego con los Mauser. Por las mañanas, después de tomar el desayuno y cuando el cielo principia a tener caprichos de puntos modernistas, marchamos a los graníticos campos de la Herradura o a los terrosos campos del camino a San Juan, con el arma a la cazadora y allí empeñamos nuestros combates con los blancos impasibles, graves, heroicos.

Cuando en mi primer ejercicio de tiro miré al blanco sobre la mira de mi carabina, no pude retener un movimiento nervioso.

Apunté y tras la explosión de la pólvora, la bala abandonó su lecho y fue a herir a el centro de uno de los seis blancos. Entonces me pareció que el blanco era un enemigo. Los disparos de mis camaradas le dieron al lugar cierto ambiente de combate y yo principié a ver moverse los blancos delante de los que las banderolas rojas eran insultantes. Entonces me decidí. Indudablemente esos enemigos blancos con sus cruces negras y sus banderas rojas, fraguaban algo contra mí. Un odio intenso me dominó y principié a disparar rápidamente, siguiendo a los enemigos que hacían mil escaramuzas sobre el Cerro. He seguido luchando, he herido a muchos de ellos, que no han caído muertos de puro punto y en mi ansia loca de matar he disparado los cinco tiros de mi carabina, he triunfado del combate, he dejado inmóviles a los blancos y durante esos segundos he sido el héroe de la batería. De improviso la voz rápida del capitán que me dice:

-¡Ese hombre no se fija. Ha herido los cinco blancos!...

y yo volviendo a la realidad de las cosas, empavado y mirándole tímidamente le he dicho:

-¡Perdóneme usted, mi capitán. Los había tomado por soldados!. ..

Y, felizmente, nadie se acordó en ese momento del calabozo. 


\subsubsection{Porcentaje de adjetivos (del total de palabras) y, del total de adjetivos, según tipo (objetivos / subjetivos)}

\begin{tabular}{l|l|l|l}
\hline Segmento & \% adjetivos & $\begin{array}{l}\text { \% adjetivos } \\
\text { objetivos }\end{array}$ & $\begin{array}{l}\text { \% adjetivos } \\
\text { subjetivos }\end{array}$ \\
\hline 1 & D 4.4 & 22.2 & 77.8 \\
\hline 2 & D 7.5 & 50 & 50 \\
\hline 3 & D 15.3 & 37.5 & 62.5 \\
\hline 4 & N 4.7 & 52 & 48 \\
\hline 5 & N 8.7 & 33.3 & 66.7 \\
\hline 6 & N 5.5 & 47.1 & 52.9 \\
\hline
\end{tabular}

El $7.7 \%$ de palabras de esta crónica son adjetivos, en promedio. En los tres primeros segmentos, predomina la descripción (D) y en los tres últimos, la narración (N). Como reflejan las cifras, la proporción de adjetivos subjetivos en las partes descriptivas (en promedio, 63.4 \%) es superior a la correspondiente a las partes narrativas (en promedio, $55.8 \%$ ). Con respecto al tono, el primer segmento refleja una actitud contemplativa, esplinática, que permite identificar una isotopía que podría denominarse «melancolía». Se asocian al sustantivo «monarca» los siguientes adjetivos: él es espléndido, su spleen es correctísimo, su sonrisa es suave, sus salones son bohemios, la sesión de su capa roja es majestuosa.

En los segmentos 2 y 3, Valdelomar sigue describiendo, pero con un aire más ligero y humorístico. Después del segmento 3, en el que el $15.3 \%$ de las palabras son adjetivos, la proporción baja significativamente al $4.7 \%$ en el segmento 4 . Estos cambios aportan ritmo al texto.

Como detalle adicional, el primer segmento refleja cosmopolitismo - característica del modernismo- al mencionarse lugares y costumbres londinenses, y al hacer un uso reiterado de términos en inglés.

La impertinencia en la relación entre nombre y adjetivo produce hipálages: «salones bohemios», "cabellos rebeldes y enérgicos», "guedeja cosmetizada y sentimental», «engañosas caricias», «viajes dudosos», «blancos impasibles, graves, heroicos». También hay impertinencia en «rojo violento», «marrón muriente», «valle eterno», «viento acariciador». En estos casos el efecto se acerca más a la metáfora o al símbolo. 


\subsubsection{Estructura}

En lo que se refiere a la distribución y ubicación de adjetivos, la estructura más usada es la del sintagma nominal seguido de un adjetivo. La estructura inversa es la segunda más empleada y, en tercer lugar, el sustantivo acompañado por dos adjetivos pospuestos.

\begin{tabular}{l|l|l|l|l|l|l}
\hline Segmento & $\mathbf{S}+\mathbf{1}^{\mathbf{a}}$ & $\mathbf{S}+\mathbf{2}^{\mathbf{a}}$ & $\mathbf{S}+\mathbf{3}^{\mathbf{a}}$ & $\mathbf{1}^{\mathbf{a}}+\mathbf{S}$ & $\mathbf{1}^{\mathbf{a}}+\mathbf{S}+\mathbf{1}^{\mathbf{a}}$ & $\mathbf{1}^{\mathbf{a}}+\mathbf{S}+\mathbf{2}^{\mathbf{a}}$ \\
\hline 1 & 5 & & & 4 & & \\
\hline 2 & 6 & 1 & & & & \\
\hline 4 & 4 & 5 & 1 & 2 & 1 & 1 \\
\hline 5 & 13 & 2 & 2 & 2 & & \\
\hline 6 & 7 & 1 & & 6 & & \\
\hline Total & 8 & 1 & 1 & 4 & & \\
\hline & $\mathbf{4 3}$ & $\mathbf{1 0}$ & $\mathbf{4}$ & $\mathbf{1 8}$ & $\mathbf{1}$ & $\mathbf{1}$ \\
\hline & $\mathbf{S}+\mathbf{1}^{\mathbf{a}}$ & $\mathbf{S}+2^{\mathbf{a}}$ & $\mathbf{S}+\mathbf{3}^{\mathbf{a}}$ & $\mathbf{1}^{\mathbf{a}}+\mathbf{S}$ & $\mathbf{1}^{\mathbf{a}}+\mathbf{S}+\mathbf{1}^{\mathbf{a}}$ & $\mathbf{1}^{\mathbf{a}}+\mathbf{S}+\mathbf{2}^{\mathbf{a}}$ \\
\hline & & & & & & \\
\hline
\end{tabular}

\subsection{Desde Roma}

Escrita: Roma, 1913.

Publicada: La Nación, 24 de enero de 1914, p. 1.

\subsubsection{Resumen}

El tema de la crónica es lo que pasó en París cuando la Mona Lisa desapareció del Louvre. Abraham Valdelomar describe esa famosa pintura y la asocia a otra de Afrodita exhibida en el mismo museo. Describe también cuál fue el efecto de la pérdida, cuáles fueron las especulaciones sobre la identidad del desconocido ladrón y cuánta sorpresa causó conocerla. Relata cómo se produjo el robo y el hallazgo, y cómo se prepara el desagravio. 


\section{Situación antes del robo}

París estaba, artísticamente, bajo la advocación de dos mujeres a cuya sombra se acogía su espíritu tranquilo como Cartago al velo de Tamt. Aquellas dos divinidades eran el símbolo de ese pueblo sabio y sensible; la forma armoniosa e inmaculada de Afrodita y el espíritu insondable y plácido de Mona Lisa, el mundo desfilaba en el Louvre ante el pedestal de Venus y comulgaba luego en el altar de Gioconda. Estas dos hermanas armoniosas eran la carne y el espíritu, la forma y la idea, el cuerpo y el alma, formaban una sola vida artística que protegía desde las orillas del Sena a la humanidad que se purificaba en la Eucaristía del arte, de las cosas intangilbles y hondas, por encima de la torpe miseria de la vida.

Extranjeras, ambas habían llegado a ser parisienses. En su altar educáronse las generaciones y la religión de su belleza difundida llegó a ser universal. Ellas vieron pasar el innúmero peregrinaje de los hombres, sintieron las miradas de todos los ojos y las fiebres de todos los entusiasmos.

\section{El robo}

Mas un día truncó se el paralelismo de esas vidas y una de las dos hermanas desapareció, la Gioconda no volvió a sonreír y París vistió de luto por mucho tiempo. La divinidad había abandonado su trono y en la tortuosa ruta de un viaje desconocido, perdióse en alas de un misterio impenetrable. Solo quedaba el cuerpo frío, el rostro sin pupilas, la pagana forma de la manca inconsolable. Venus quedóse dueña de París.

\section{Efectos del robo}

Desde aquel día, algo faltó a la ciudad encantada y al espíritu francés, faltaba una de sus más dulces complacencias; porque para aquella ciudad inquieta, la mirada de Mona Lisa era como un refugio de espiritualismo en medio del cotidiano tormento. Los visitantes al Louvre, al salir, ya no tenían ese gesto de peregrinos que han bebido en la fuente fresca y tranquila; ya en el templo de las bellezas no existía la sonrisa inefable, la gracia encantadora, la mirada 
profunda, las manos mórbidas, la paz misteriosa del paisaje florentino. Y notábase en los que salían un vago gesto de melancólico desencanto.

\section{Reacción de medios, parisinos y artistas}

De vez en cuando aparecía en los diarios una vaga esperanza a dos columnas, mas al día siguiente se callaban, y como nadie sabía el paradero, todos señalaban algún nuevo camino.

... Por fin calláronse los diarios, enmudecieron los artistas y se buscó algo que hiciera disipar el recuerdo lacerante. Todo París se echó en brazos del tango argentino, en medio de cuyas rítmicas volutas, los más horribles recuerdos se disipan. Los que no estaban a la altura del tango se dedicaron a inventar pistas y a imaginarse al ladrón. Se creó una literatura giocondinesca. D’Annunzio empezó a escribir un libro: El Hombre que ha robado la Gioconda...

\section{Especulaciones sobre el ladrón}

El ladrón en la fantasía parisién.

Siendo la Gioconda una obra «invendible», creíase que el ladrón no fuese un pobre diablo. Se decía que la obra había sido robada por algún «ser superior», por algún artista, o un excéntrico, o un desequilibrado. Para unos, el ladrón era una especie de Monsieur Phocas, que obsesionado por la sonrisa de la obra lconardesca, la había robado para contemplarla solo y en paz. Se habló de un lord inglés, uno de esos personajes de Oscar Wilde, morfinómano y esplinático. Dijeron algunos que un millonario yanqui la había llevado a su país; otros hablaban de un pintor francés y quienes de un iconoclasta judío. Para éstos el ladrón era blanco, rubio, depilado; para aquéllos moreno, pálido, de barbas; para algunos era un hindú pero estaban de acuerdo en que no era un hombre vulgar sino un espíritu exquisito y refinado, capaz de comprender la maravilla de Leonardo. Era un caso de sentimentalismo artístico, de neurastenia aguda, de monomanía, de alguna de esas enfermedades que lo ponían muy por encima, moralmente, de los celptómanos de oficio, de los apaches de boulevard, o de los monedares falsos. 


\section{Hallazgo}

Por eso cuando se tuvo la confirmación del hallazgo todos se preguntaron: -¿Quién es el ladrón?...

Pequeños comentarios sobre el ladrón de la Gioconda, o sea, sobre Vicente Peruggia.

\section{Descripción del ladrón}

Oh, desencanto, oh ilusiones rotas de la vida, oh duro choque de la realidad que nos sorprende. Los que caen del encumbrado situal de la fantasía obsesionados que no existen, neurasténicos que no roban, iconoclastas que no destruyen, Monsieur Phocas que duerme en los anaqueles terrosos de alguna librería. Ninguno de esos señores ha robado la divina obra de Vinci. El ladrón ... es un hombre. Un hombre como cualquier otro. Bajito, metido en carnes, sucio, cursi, estúpido, necio y bellaco. Vulgar hasta en el tamaño, que no es ni alto ni bajo. De una mediocridad repugnante. De una imbecilidad ofensiva. Ni abiertamente lombrosiano, ni claramente normal; ni tan bruto como para dejarse coger al cometer el robo ni fue tan hábil para librarse de la cárcel con una respuesta atinada. Carece de todas las agravantes morales que le pudieran disculpar el robo, no es poeta ni pintor, ni periodista. ¿Con qué derecho se robó la Gioconda? En fin, es un cretino, que no merecía haber tenido entre los muros húmedos de su buhardilla, y bajo las telarañas de su colchón, la obra maestra de los siglos, la imagen de aquella mujer a la cual el divino Leonardo no le fue dado tocar con sus sabias y expertas manos.

\section{Explicación del robo, del hallazgo y del desagravio en Florencia}

De las torturas y malandanzas de la Gioconda durante los dos años de su ausencia, y al lado del cretino.

Al ser innoble, catalogado ya en la cárcel de Florencia, y que trato de gentes bien, llamó se Vicente Peruggia, ha narrado la historia de su robo; él era empleado en el Louvre, y aunque de arte no sabe absolutamente nada, indignábase siempre de que los extranjeros aplaudieran las obras más celebradas 
del Museo, entre las cuales había muchas italianas. A él le habían dicho que Napoleón habría sido un señor muy poderoso pero muy ladrón, que no se ocupaba de otra cosa que de robarse cuadros y que muchos, todos los de Louvre, eran robados de Italia por Napoleón. Entonces nació en él el deseo de venganza. Concibió el robo, y una mañana aprovechando de que no le veían, descolgó del muro la divina tela y se la ocultó; bajo la blusa de Vicente, atravesó las calles de París para ir a alojarse debajo de una cama inmunda y allí ha estado la Divina Mujer, durante dos años, en la innoble compañía de ratas, arañas, humedad y mal olor. Un día emprendió viaje a su tierra, iba en una caja de humildísimo abeto, junto con la ropa sucia del patriota que la conducía, sobre ella había zapatos rotos, calcetines usados y otras prendas de vestir de más intimidad. De allí pasó a la prefectura y recuperada por las autoridades policiales y artísticas, pudo ver la luz en la Galleria degli Uffici, en Florencia, aquella patria de genios, de donde saliera en un lejano día. Florencia envió aquel mismo día al palacio a unos cincuenta mil florentinos que desfilaron ante el cuadro, en desfile caballeresco, en homenaje a la obra y al genio italiano que le diera vida. Aquella sola manifestación, de tan delicada cortesanía, sería suficiente para desagraviar a Mona Lisa de los vejámenes sufridos en poder de Peruggia.

\section{Anuncio del desagravio en Roma}

La obra vendrá en breve a Roma y se exhibirá en Villa Medici. Toda la ciudad se prepara a recibirla y a rendirle pleitesía en tanto en París se organizan grandes fiestas, para celebrar su vuelta, el día que atraviese de nuevo los pasillos del Louvre, el día en que su hermana Afrodita la vea pasar, en cortejo triunfal, por el mismo sitio por el cual en una mañana trágica, sus ojos sin pupila no la descubrieron bajo la blusa azul de aquel bellaco ...

Los honores en Roma.

Periodistas, universitarios, hombres de fama e ingenio, han pedido al Ministerio de Relaciones que Gioconda sea expuesta en esta ciudad. El sábado aparecerá la obra en Villa Medici. Sabido es que Leonardo de Vinci dio sus últimos toques al lienzo, en Roma. Aquí pues, donde por primera vez se insinuara su sonrisa, va a ser admirada, aquí en la paz de la ciudad antigua, donde Leonardo fijara la dulce placidez, la casta mirada, aquel 
ensueño cándido, el espíritu inmutable, lo que hay de más puro y divino en una alma selecta, la suave insinuación de una sonrisa...

\subsubsection{Porcentaje de adjetivos (del total de palabras) y, del total de} adjetivos, según tipo (objetivos / subjetivos)

\begin{tabular}{l|l|l|l}
\hline Segmento & \% adjetivos & $\begin{array}{l}\text { \% adjetivos } \\
\text { objetivos }\end{array}$ & $\begin{array}{l}\text { \% adjetivos } \\
\text { subjetivos }\end{array}$ \\
\hline 1 & D 10.3 & 38.9 & 61.1 \\
\hline 2 & N 8.1 & 33.3 & 66.7 \\
\hline 3 & D 14.7 & 33.3 & 66.7 \\
\hline 4 & N 6.5 & 71.4 & 28.6 \\
\hline 5 & D 11.5 & 72.7 & 27.3 \\
\hline 6 & N 3.3 & 100 & 0 \\
\hline 7 & D 13.4 & 37.1 & 62.9 \\
\hline 8 & N 7.2 & 69.6 & 30.4 \\
\hline 9 & N 5.9 & 27.3 & 72.7 \\
\hline
\end{tabular}

En el primer segmento, como en otros inicios, Valdelomar adopta una actitud contemplativa y esplinática al describir entorno y personajes. Se puede encontrar ahí una isotopía relacionada con el culto, con la actividad espiritual, y esto se exalta en oposición a «la torpe miseria de la vida». Luego pasa a narrar e intercala descripción y narración casi hasta el final. En todos los segmentos descriptivos el porcentaje de adjetivos es superior a $10 \%$, mientras en las partes donde predomina la narración los adjetivos solo superan ligeramente el $8 \%$.

El segundo segmento, donde el autor narra lo que pasó (el robo), empieza con pocos adjetivos y estos se vuelven numerosos y subjetivos para enfatizar el signo negativo del hecho relatado. Esta forma de adjetivación se mantiene en el tercer segmento, cuando Valdelomar adopta nuevamente una actitud esplinática para referirse a la situación tras la desaparición de la pintura. En el cuarto segmento narra y en el quinto describe, y en ambos casos usa un alto porcentaje de adjetivos objetivos (más del $70 \%$ ), que alcanzan el $100 \%$ en el sexto segmento.

Luego de ese extremo, cambia radicalmente el tipo de adjetivos. Estos se vuelven mayoritariamente subjetivos (casi $63 \%$ ) en el sétimo segmento, bajan en el octavo segmento y suben a su nivel más alto (72.7\%) en el segmento final. Por tanto, no 
se puede establecer una relación de correspondencia entre la opción descripción / narración y el tipo de adjetivos (objetivos / subjetivos). Al parecer, el tipo de adjetivos se adecúa a la necesidad de destacar la contundencia de los hechos o las emociones que provocan. Por ejemplo, en el sétimo segmento, la descripción del ladrón está llena de adjetivos que intensifican la actitud del autor — sorprendida, indignada, despectiva - hacia el personaje.

En promedio, son adjetivos el $9 \%$ de las palabras; son subjetivos el $54.5 \%$ de los adjetivos que son parte de las descripciones y el $39.7 \%$ de los que aparecen en las narraciones.

Por otra parte, la impertinencia es visible al atribuirle cualidades y propiedades humanas a la ciudad («París vistió de luto»), a Venus («manca inconsolable») y a Gioconda («la divina mujer»). Se percibe una dicotomía entre lo humano (criticable) y lo no humano (admirable). Aunque el arte sea un producto humano, lo que Valdelomar ensalza es el resultado, la obra de arte, y la opone a las personas $(\tan )$ comunes y $(\tan )$ corrientes.

\subsubsection{Estructura}

El esquema correspondiente a un sustantivo seguido de un adjetivo $(\mathrm{S}+1 \mathrm{~A})$ es el predominante. Aparece casi el doble de veces que el segundo esquema más usado $(1 \mathrm{~A}+\mathrm{S})$. En tercer lugar está el sustantivo seguido de dos adjetivos y, como caso excepcional, un sintagma nominal va con siete adjetivos pospuestos.

\begin{tabular}{l|l|l|l|l|l|l|l|l}
\hline Segmento & $\mathbf{S}+\mathbf{1}^{\mathbf{a}}$ & $\mathbf{S}+\mathbf{2}^{\mathbf{a}}$ & $\mathbf{S}+\mathbf{3}^{\mathbf{a}}$ & $\mathbf{S}+4^{\mathbf{a}}$ & $\mathbf{S}+\mathbf{7}^{\mathbf{a}}$ & $\mathbf{1}^{\mathbf{a}}+\mathbf{S}$ & $\mathbf{2}^{\mathbf{a}}+\mathbf{S}$ & $\mathbf{1}^{\mathbf{a}}+\mathbf{S}^{\mathbf{a}}$ \\
\hline 1 & 4 & 4 & & & & 2 & & 2 \\
\hline 2 & 4 & & & & & 2 & & \\
\hline 3 & 9 & 1 & & & & 4 & & \\
\hline 4 & 3 & & & & & 3 & & \\
\hline 5 & 12 & 2 & 2 & & & & & \\
\hline 6 & & & & & & 1 & & \\
\hline 7 & 8 & & 1 & 1 & 1 & 4 & 1 & \\
\hline 9 & 7 & 4 & & & & 8 & & \\
\hline Total & 7 & & & & & 4 & & \\
\hline & $\mathbf{5 4}$ & $\mathbf{1 1}$ & $\mathbf{3}$ & $\mathbf{1}$ & $\mathbf{1}$ & $\mathbf{2 8}$ & $\mathbf{1}$ & $\mathbf{2}$ \\
\hline & $\mathbf{S}+\mathbf{1}^{\mathbf{a}}$ & $\mathbf{S}+\mathbf{2}^{\mathbf{a}}$ & $\mathbf{S}+\mathbf{3}^{\mathbf{a}}$ & $\mathbf{S}+\mathbf{4}^{\mathbf{a}}$ & $\mathbf{S}+\mathbf{7}^{\mathbf{a}}$ & $\mathbf{1}^{\mathbf{a}}+\mathbf{S}$ & $\mathbf{2}^{\mathbf{a}}+\mathbf{S}$ & $\mathbf{1}^{\mathbf{a}+\mathbf{S}+\mathbf{1}^{\mathbf{a}}}$ \\
\hline
\end{tabular}




\section{María del Carmen Sala}

\subsection{Dando el opio...}

Publicada: La Prensa, 10 de octubre de 1916.

\subsubsection{Resumen}

Como cronista parlamentario, Abraham Valdelomar elaboró textos que daban cuenta de la actividad desarrollada en el Congreso de la República, en un tono irreverente, cargado de sarcasmo. Esta crónica se divide en dos partes. La primera presenta relata lo ocurrido cuando un congresista (Secada) tuvo una intervención muy larga y soporífera: fue tan larga y soporífera que el ministro (García Bedoya), que asistía a la sesión, se quedó dormido. En la segunda parte, el autor cuenta que un congresista (Balbuena) regaló relojes a los periodistas, con los que podían medir la extensión de las intervenciones del parlamentario más locuaz.

\section{Descripción de la sesión}

Larga, pesada, brumosa, asfixiante, descabalada, paradojal, estéril, contradictoria, ilógica, soporífera, inquisitorial, palurda y canija, fue la sesión de ayer en Diputados. Hubo cosas inusitadas y sorprendentes.

\section{Enumeración de oradores}

Habló el señor Escardó sobre el azúcar y nos dejó con la miel en los labios. Habló el distinguido y trasandino señor Urbina, no sobre el azúcar sino sobre la sal, que, según él, pesa sobre el resto del país. «Lima, no es el Palais Concert», dijo el señor Urbina. Pero su señoría, que es muy salado, como buen huantino, se estrelló contra el señor Zapata. Habló también, defendiendo al militarismo, con gesto de Kaiser chinchano, el señor Moreno, que tuvo una elocuencia de teniente coronel.

Vino la cuestión de los telegrafistas. Y vino, como no podía dejar de venir, el discurso del señor Secada. 


\section{Comentarios sobre congresista Secada}

El señor Secada no quiere estarse callao. El que tan altruista campaña ha hecho contra el opio, aquella droga desmoralizadora y nociva, que hacer dormir más de lo natural y transforma a cada hombre en un lirón, prodiga el opio delicado y fino de su oratoria. El señor Secada que da el opio con tanta frecuencia debía pagar un impuesto cada vez que toma la palabra. El Estado ya sería rico. Pero su señoría ha nacido para hablar, es orgánicamente locuaz.

\section{Discurso de Secada y reacciones}

Su señoría pronunció ayer un discurso digno de las palabras que encabezan el cuerpo de este artículo. Habló, Habló. Habló. Cabeceaba desde su banco, con su rostro apimentado, el señor Ráez. Cabeceaba, resignado eI señor Aramburú. Cabeceaba con su nariz de fauno, el señor Luna Iglesias. Cabeceaban los periodistas. Cabeceaba la Cámara. Cabeceaban el mundo, el espacio, el tiempo, la luz eléctrica. No cabeceaba el propio señor Secada porque su señoría, cuando habla, pierde la cabeza.

Amenguada la voz por el exceso, sólo se veía en la sala, la jacobina figura del señor Secada que abría, cerraba, esgrimía, levantaba, agitaba y extendía los brazos. Parecía, casi en silencio, un juguete de Pascua. Agotados los argumentos, recurrió a los libros. Abrió uno de los muchos que le acompañaban y leyó, leyó, leyó. La cámara seguía cabeceando. Hubo de recurrir, para despertarla, a la revuelta. Y dejado la lectura comenzó una conferencia sobre la rebeldía, la rebelión, la revelación y la revolución. El derecho a la huelga. Salió a sonar el señor González Prada, el maestro Máximo. Salió a relucir el señor Zapata. Y salió a relucir el reloj del ilustre señor Ulloa que marcaba las ocho.

\section{Reacción de García Bedoya a discurso de Secada}

Cuando le dieron las ocho al señor Secada, levantó la voz para evitar que el presidente levantara la sesión. Y a sus gritos, que eran estertores, alzó la cabeza el señor García Bedoya. 
-¡El desayuno! -exclamó azorado, restregándose los ojos.

El señor ministro se había quedado dormido! En tanto el señor Químper decía, consolando al diputado por el Callao:

-Ha puesto useñoría en un hilo el señor ministro.

Y el señor García Bedoya, que es de la cuerda, le respondió:

-Sí. Pero ha sido en un hilo telegráfico...

\section{Diálogo con el congresista Balbuena}

Dando la hora ...

Ayer vino hasta nuestra mesa de periodistas, dispensándonos honor tamaño, y remarcable, el señor Balbuena, nuestro colega.

-¿Qué hora tenéis, gentiles colegas?

-Nosotros, honorable señor, no tenemos hora. Sólo tenemos una hora fija: la de la muerte! Los periodistas, honorable señor, somos casi franciscanos.

No tenemos nada. Hasta la vergüenza va siendo artículo de lujo...

-¿Pero no tenéis relojes? ¿Cómo consultáis el tiempo? ..

-Por los apremios estomacales, honorable señor...

-Que son crueles...

-Pero sinceros.

-Pues yo os daré la hora.

-Useñoría siempre da la hora...

\section{Balbuena entrega relojes a periodistas}

Y el señor Balbuena salió para volver a poco con un paquete.

Un paquete de relojes. Walham. Longines. Tres picos. Relojes grandes. Relojes de pulsera. Al verlo le cantamos en coro lo de la zarzuela...

Quería que me ablandara.

Con un relojito de esos de pulsera... Y se ló...

El señor Balbuena parecía una sucursal de Welsh. Extendió la mano, con un ademán de Mecenas trigueño y pródigo y nos dijo, magnánimo:

-¡Escoged! ¡Elegid! ¡Poseed! ¡Enriquecéos!..

Y escogimos, elegimos y poseímos reloj. 


\section{Consecuencias del regalo de relojes}

Gracias a la munificencia del señor Balbuena le podemos tomar la hora a los discursos del señor Secada. Los periodistas esperamos que en el reloj del tiempo y en los del señor Balbuena, suene la hora máxima en que el pueblo de Lima, "como un solo hombre», vaya a las ánforas y elija al señor Balbuena.

El señor Balbuena, como lo dijimos siempre, mucho antes de la escena de los relojes, es el único, el primero, el mejor, el irremplazable ciudadano que debe representar a la capital en el parlamento. Orador distinguido y ciceroniano. Gentleman intachable. Mecenas pródigo. Supremo profesional. Elegante. ¿Quién dice que el señor Balbuena es amarsigado? Inexactitud diatribesca y tamaña! Useñoría es hasta buen mozo.

Useñoría no debe ir a un banco de diputado. Debe ocupar un ministerio. ¿Ministerio? Más que ministerio. Presidente de gabinete. Más que presidente de gabinete. Su señoría debe ser, y será, mientras tenga relojes, con el tiempo, presidente de la república.

Un ciudadano que ha levantado el nivel moral de los electores! Antes los candidatos obsequiaban al elector butifarras y chicha. Ahora los candidatos regalarán relojes!

\section{Diálogo de periodistas con Balbuena}

-A ver -nos dijo al concluir la sesión- si han hecho ya uso de mi modesto obsequio. ¿Qué tiempo ha hablado el señor Secada?

-Cinco horas! -le respondimos.

-jJi! ¡ji! ¡ji! Si no ha hablado más de hora y cuarto...

-Entonces sus relojes, honorable señor, tienen las horas muy largas... 


\subsubsection{Porcentaje de adjetivos (del total de palabras) y, del total de adjetivos, según tipo (objetivos / subjetivos)}

\begin{tabular}{l|l|l|l}
\hline Segmento & \% adjetivos & $\begin{array}{l}\text { \% adjetivos } \\
\text { objetivos }\end{array}$ & $\begin{array}{l}\text { \% adjetivos } \\
\text { subjetivos }\end{array}$ \\
\hline 1 & D 57.7 & 6.7 & 93.3 \\
\hline 2 & N 4.8 & 60 & 40 \\
\hline 3 & D 9.9 & 37.5 & 62.5 \\
\hline 4 & N 3.6 & 42.9 & 57.1 \\
\hline 5 & N 3.4 & 100 & 0 \\
\hline 6 & N 11.1 & 10 & 90 \\
\hline 7 & N 4.9 & 50 & 50 \\
\hline 8 & D 9.2 & 52.9 & 47.1 \\
\hline 9 & N 6 & 0 & 100 \\
\hline
\end{tabular}

Una vez más, Valdelomar empieza una crónica con una descripción en la que incluye numerosos adjetivos y todos ellos parten de su apreciación subjetiva de los hechos ocurridos en el Congreso de la República (Larga, pesada, brumosa, asfixiante, descabalada, paradojal, estéril, contradictoria, ilógica, soporífera, inquisitorial, palurda y canija, fue la sesión...). Se le atribuyen al sintagma nominal «sesión de Diputados» adjetivos (subjetivos en un 93.3 \%) asociados a la ineficacia, el caos, la pérdida de tiempo. Esta insistencia confirma la valoración negativa que hace Valdelomar de las actividades humanas.

Luego de esa descripción corta y contundente, el autor entra de inmediato a uno de varios segmentos narrativos, que están atravesados por el humor. En el segundo segmento hace incluso juego de palabras (sal /salado) y crea frases ingeniosas para calificar a los personajes (gesto de Kaiser chinchano, elocuencia de teniente coronel). En los dos segmentos siguientes hay un despliegue de figuras retóricas. Las siguientes son algunas de ellas.

- Ironía: "prodiga el opio delicado y fino de su oratoria»

- Anáfora: «Habló, Habló. Habló.» «...y leyó, leyó, leyó.» «Cabeceaba desde su banco, con su rostro apimentado, el señor Ráez. Cabeceaba, resignado el señor Aramburú. Cabeceaba con su nariz de fauno, el señor Luna Iglesias. Cabeceaban los periodistas. Cabeceaba la Cámara. Cabeceaban el mundo, el espacio, el tiempo, la luz eléctrica.» 
- Hipérbole: «Cabeceaban el mundo, el espacio, el tiempo, la luz eléctrica.»

- Juego de palabras: «No cabeceaba el propio señor Secada porque su señoría, cuando habla, pierde la cabeza.»

- Paranomasia o aliteración: «Hubo de recurrir, para despertarla, a la revuelta. Y dejado la lectura comenzó una conferencia sobre la rebeldía, la rebelión, la revelación y la revolución.»

Por tratarse de una crónica parlamentaria, lo principal es el relato, y las figuras retóricas son una manera de sazonar e interpretar los hechos. Los segmentos quinto, sexto, sétimo y noveno incluyen diálogos que se presentan como reales. El octavo segmento concentra la mirada humorística, burlona, del autor.

En promedio, el $12.3 \%$ de palabras son adjetivos y los adjetivos subjetivos son el $67 \%$ en las descripciones y el $56.1 \%$ en las narraciones.

\subsubsection{Estructura}

Lo más usado sigue siendo un adjetivo pospuesto (18 veces) y, en segundo lugar, uno antepuesto (14 veces), pero las diferencias entre ambas estructuras no es muy grande (4). En tercer lugar, está el esquema formado por un sustantivo seguido de dos adjetivos ( 7 veces) y como caso excepcional, un sustantivo precedido por 13 adjetivos.

\begin{tabular}{l|l|l|l|l|l|l|l}
\hline Segmento & $\mathbf{S + 1 A}$ & $\mathbf{S + 2 A}$ & $\mathbf{S + 3 A}$ & $\mathbf{1 A + S}$ & $\mathbf{2 A + S}$ & $\mathbf{4 A + S}$ & $\mathbf{1 3 A + S}$ \\
\hline 1 & & 1 & & & & & 1 \\
\hline 2 & 1 & 1 & & & 1 & & \\
\hline 3 & 3 & 2 & & 1 & & & \\
\hline 5 & 2 & & & 5 & & & \\
\hline 6 & 3 & & & & & & \\
\hline 7 & 1 & 1 & 1 & 4 & & & \\
\hline 8 & 1 & & 1 & & & & \\
\hline 9 & 6 & 2 & & 2 & & 1 & \\
\hline Total & 1 & & & 2 & & & \\
\hline & $\mathbf{1 8}$ & $\mathbf{7}$ & $\mathbf{2}$ & $\mathbf{1 4}$ & $\mathbf{1}$ & $\mathbf{1}$ & $\mathbf{1}$ \\
\hline & S+1A & $\mathbf{S + 2 A}$ & $\mathbf{S + 3 A}$ & $\mathbf{1 A + S}$ & $\mathbf{2 A + S}$ & $\mathbf{4 A + S}$ & $\mathbf{1 3 A}+\mathbf{S}$ \\
\hline
\end{tabular}




\subsection{La primera hoja seca...}

Dedicada: A Sofi.

Firmada: El Conde de Lemos.

Publicada: En la columna «Fuegos fatuos».La Prensa, 26 de noviembre de 1916, p. 6.

\subsubsection{Resumen}

El autor empieza esta crónica describiendo qué son los fuegos fatuos y explicando por qué ha titulado así su columna periodística. Después describe el lugar desde donde contempla el mar (alameda en Magdalena) y lo que observa (el mar agitado). Las acciones son mínimas: se descubre una cana, reflexiona sobre su significado, imagina lo que ella le dice, le contesta y la lanza al viento.

\section{Descripción de fuegos fatuos}

Durante las noches de estío, en los cementerios aldeanos, allí donde sepultan a los muertos bajo la hierba húmeda, en pleno regazo de la tierra, en el íntimo albergue de la naturaleza, cuando llueve, en la estación ubérrima y fecunda, sobre la extensión florecida, bajo los constelados cielos del verano, suelen encenderse sobre las tumbas, lucecillas precarias, azulinas, breves y cambiantes, que los hombres llaman fuegos fatuos. Creían las razas pretéritas, que tales luces eran formas, solicitaciones, mudo lenguaje del alma de hombres sepultos, pero Berthelot, al mismo tiempo que fabricaba albúmina en sus laboratorios, explicaba el proceso químico de los gases producidos por la descomposición de la carne; y lo que antes se expresaba en oraciones y salmos se expresó por él en una fórmula química, en la que había carbono, oxígeno, azogue...

\section{Presentación de columna «Fuegos fatuos»}

Luces raras que nacen en los camposantos, fuerzas que impulsa la muerte, colores vanos que alientan la forma corpórea corrompida, fuegos fatuos que surgen en mi espíritu sobre tantas ilusiones muertas, tales estos artículos breves y luminosos que te ofrezco, lector selecto. Fugaces y vanas lágrimas de luz, última radiación de la vida que se extingue, lucecillas que corren un 
instante sobre la magnífica fertilidad indiferente de los cementerios, fuegos fatuos que nacen en mi cerebro cansado y joven donde hay tantas, $\tan$ dulces, tan bellas, tan radiantes, tan amadas cosas sepultas...

3 Descripción del lugar donde mira el mar y del mar

La línea eléctrica que sale de la rotonda donde se yergue el héroe legendario, recorre una alameda a trechos pobre y exuberante a trechos, formada por sauces raquíticos, ficus broncíneos y palmeras aladas, terminando en paralelos laureales, que en el estío florecen en rosa, y va a concluir en aldehuela que se llama Magdalena del Mar. De allí parten dos caminos: una alameda bordeada de pinos jóvenes y erectos que va al filo de barrancos hasta Miraflores y otro, el del norte, que lleva, tras poco caminar, a una suerte de bajada, abra, quebrada o barranco, por la cual expertos excursionistas pueden, sin mayor peligro, llegar hasta la pedregosa orilla que humedecen las marinas olas.

Allí el mar es violento y tiene voces homéricas. Las olas nacen, lejos de la costa, con sus imprecisos lomos verdes que crecen hasta coronarse de crestas reventonas sobre el redondo lomo deleznable y monstruoso, que rueda fatal hasta la playa, y azotándola con violencia y saña, se extiende sobre ella con la gracia majestuosa de un abanico o de una capa de torero, capa verde rodeada de encajes blancos, que, como caen cual res, al retirarse arrancan consigo millares de piedras que producen ruido amedrentador y sordo. Cruza, de vez en cuando, por la extensión lejana, la latina vela sobre el frágil barco pescador, o el par de alas impolutas de alguna ave solitaria, mientras el sol luce las galas de una agonía sangrienta.

\section{Conversación con el mar y descubrimiento de la cana}

Conversamos en silencio, con los ojos. Una ola me traía sus preguntas y en otras ola le mandaba yo a la insaciada de mis pensamientos, mis respuestas mudas-elocuentes. La mano blanca, fina, suave, menuda y blanda, se posó en mis cabellos como una ala de gaviota y me ofreció el presente doloroso, el hilo de cabello blanco, de una cana. Y viví el momento. 


\section{$5 \quad$ Significado de la cana}

La primera cana es el primer aviso. Es como el primer fruto maduro del árbol fecundo. Es en su fina delicadeza plateada, como la espada del tiempo inexorable. Es la síntesis de todos los pasados dolores, de todas las tristezas enterradas, de todas las horas desvanecidas, la voz de la vida que pudo ser estéril. La primera cana es como una condenación de la vida, el diploma de la carrera vencida, el mudo símbolo del trabajo, el sabio y prudente aviso del tiempo, la primera sonrisa de la Muerte. Sólo delante de ella se piensa en muchas cosas en que nunca se pensará.

\section{Diálogo con la cana}

La primera flor de plata, en la mano blanda, fina, suave, menuda y blanca, bajo su honda mirada dulce y bajo mi débil mirada triste, me habló de esta guisa al ánimo:

-¡Eh! Señor Peregrino. Detente y descansa. Tienes sed, bebe en el azul arroyo del cielo. Harta tu deseo y escucha. Esta es la mitad del camino. ¿Qué has hecho? ¿Qué haces? ¿Qué vas a hacer’? ¿Sabes ya quién eres? ¿Sabes ya de dónde has venido? ¿Sabes ya cuál es tu fin? Yo he madurado sobre tu cerebro, he sentido correr bajo mis raíces, inquietas, tus ideas; he sentido el ajetreo, la labor febril, la actividad radiante de ellas: ahora yo te detengo en el camino. Te falta poco, muy poco para recorrer y aún no has elegido. ¿Vas de frente contra la vida? ¿Vas sumisamente con ella? ¿Eres un rebelde? ¿Eres un sumiso? ¿Sacrificarías tu presente tangible y real por un futuro improbable que no conoces ni has comprobado? ¿No piensas que a grandes pasos la trágica silueta de la Segadora se encamina hacia ti? Piensa. Medita. Razona. Ve el cielo, el mar, el cementerio, la Muerte. ¿Quieres vivir?

¿Quieres morir? Habla. ¿Qué quieres?...Yo cogí la fina hebra plateada, la miré un instante con tristeza, y le dije:

-Nada... No quiero nada... 


\section{$7 \quad$ El final de la cana}

Y la arrojé al viento y se perdió en la brisa marina, húmeda, fría, sonora, oliente a yodo, mientras las tinieblas compactas caían sobre el inmenso mar agitado...

\subsubsection{Porcentaje de adjetivos (del total de palabras) y, del total de adjetivos, según tipo (objetivos / subjetivos)}

\begin{tabular}{|l|l|l|l|}
\hline Segmento & \% adjetivos & $\begin{array}{l}\text { \% adjetivos } \\
\text { objetivos }\end{array}$ & $\begin{array}{l}\text { \% adjetivos } \\
\text { subjetivos }\end{array}$ \\
\hline 1 & D 13.4 & 66.7 & 33.3 \\
\hline 2 & D 22.8 & 9.5 & 90.5 \\
\hline 3 & D 15 & 66.7 & 33.3 \\
\hline 4 & N 14.1 & 22.3 & 77.7 \\
\hline 5 & D 18.4 & 79 & 21 \\
\hline 6 & N 10.7 & 21.7 & 78.3 \\
\hline 7 & N 28.6 & 100 & 0 \\
\hline
\end{tabular}

En promedio, el porcentaje de adjetivos en esta crónica es mayor al de las tres anteriores (17.6\%), probablemente porque quien observa y escribe, además de ser el protagonista de la crónica, fija su atención en sus vivencias y su mundo interior. Hay más segmentos descriptivos y son más extensos; y, tanto en ellos como en los narrativos, prima una actitud esplinática que no deja casi espacio para el humor.

En el segundo segmento, donde Valdelomar presenta la columna «Fuegos fatuos» y justifica este título, la actitud esplinática se refuerza con la isotopía de la muerte, evidente por la coincidencia de los siguientes términos: cementerios, sepultan, muertos, tumbas, mudo, sepultos, descomposición de la carne, oraciones y salmos, camposantos, muerte, forma corpórea corrompida, espíritu, muertas, última radiación de la vida que se extingue, cementerios, cansado, sepultas. En ese mismo párrafo se puede encontrar también una isotopía referida a la luz, sugerida por la presencia de palabras como luces, colores, luminosos, lágrimas de luz, radiación, lucecillas y radiantes. 


\section{María del Carmen Sala}

Esta crónica es, entre las cuatro analizadas, la que podría considerarse más literaria, pues contiene mayor cantidad de figuras retóricas.

1er. segmento

- Metáfora: pleno regazo de la tierra.

- Hipálage: íntimo albergue de la naturaleza, estación ubérrima y fecunda. 2do. segmento

- Metáforas: luces que nacen en los camposantos, lágrimas de luz, ilusiones muertas, última radiación de la vida que se extingue.

- Hipálage: colores vanos, magnífica fertilidad indiferente, cerebro cansado y joven.

- Sinestesia: tan dulces...cosas sepultas.

3er. segmento

- Metáforas: sauces raquíticos, ficus broncíneos, palmeras aladas, el mar es violento y tiene voces homéricas, las olas nacen (...) con sus imprecisos lomos verdes que crecen hasta coronarse de crestas reventonas sobre el redondo lomo deleznable y monstruoso, el sol luce las galas de una agonía sangrienta.

- Oxímoron: ruido sordo.

4 to segmento

- Sinestesia: Conversamos en silencio, con los ojos.

- Metáfora: Una ola me traía sus preguntas y en otras ola le mandaba yo... mis respuestas.

- Oxímoron: mis respuestas mudas-elocuentes.

- Símil: la mano se posó en mis cabellos como una ala de gaviota.

5to. segmento

- Metáforas: tristezas enterradas, horas desvanecidas, la voz de la vida que pudo ser estéril, primera sonrisa de la Muerte, mudo símbolo del trabajo, sabio y prudente aviso del tiempo.

- Hipálage: árbol fecundo.

- Símil: como el primer fruto maduro del árbol fecundo, como la espada del tiempo inexorable, como una condenación de la vida

- Símbolo: La primera cana es el primer aviso, (...) la síntesis de todos los pasados dolores, de todas las tristezas enterradas, de todas las horas desvanecidas, la voz de la vida que pudo ser estéril, el diploma de la carrera vencida, el mudo símbolo del trabajo, el sabio y prudente aviso del tiempo, la primera sonrisa de la Muerte.

$84 \quad$ Lengua \& Sociedad 
6to. segmento

- Sinestesia: honda mirada dulce.

- Hipérbaton: he sentido correr bajo mis raíces, inquietas, tus ideas.

- Metáfora: la primera flor de plata, azul arroyo del cielo, labor febril, actividad radiante.

- Hipálage: débil mirada triste.

- Símbolo: la trágica silueta de la Segadora.

- Anáfora: En el cuarto segmento aparece el sustantivo «mano» con cinco adjetivos pospuestos: blanca, fina, suave, menuda y blanda. Y en el sexto segmento se repite el sustantivo y los cinco adjetivos pero en un orden ligeramente distinto: «la mano blanda, fina, suave, menuda y blanca».

Con respecto al tipo de adjetivos, la descripción contenida en el segundo segmento tiene $90.5 \%$ de adjetivos subjetivos y la narración contenida en el sétimo segmento carece de adjetivos subjetivos. Pero este dato no es parte de una regla, pues hay descripciones con bajos niveles de adjetivos subjetivos (el tercer segmento, $33 \%$ y el quinto, $21 \%$ ) y narraciones con pocos adjetivos objetivos (el cuarto, $22.3 \%$ y el sexto, $21.7 \%$ ).

\subsection{Estructura}

Como en las otras tres crónicas, lo que más se repite es $\mathrm{S}+1 \mathrm{~A}$ (sustantivo con un adjetivo pospuesto, 44 veces) $\mathrm{y}$, en un distante segundo lugar, $1 \mathrm{~A}+\mathrm{S}$ (sustantivo con un adjetivo antepuesto, 23 veces). La principal diferencia radica en que el tercer esquema más empleado es $1 \mathrm{~A}+\mathrm{S}+1 \mathrm{~A}$ (sustantivo con un adjetivo antepuesto $\mathrm{y}$ otro pospuesto, 9 veces).

\begin{tabular}{|l|l|l|l|l|l|l|l|l|l|}
\hline Seg. & $\mathbf{S + 1 A}$ & $\mathbf{S}+\mathbf{2 A}$ & $\mathbf{S + 4 A}$ & $\mathbf{S + 5 A}$ & $\mathbf{1 A + S}$ & $\mathbf{2 A + S}$ & $\mathbf{4 A + S}$ & $\mathbf{1 A + S}+\mathbf{1 A}$ & $\mathbf{1 A + S}+\mathbf{2 A}$ \\
\hline 1 & 8 & 1 & 1 & & 4 & & & & \\
\hline 2 & 7 & 2 & & & 1 & 1 & 1 & 1 & \\
\hline 3 & 15 & 3 & & & 6 & & & 2 & 1 \\
\hline 4 & 2 & 1 & & 1 & & & & & \\
\hline 5 & 6 & & & & 7 & 1 & & 2 & \\
\hline 6 & 5 & 1 & & 1 & 5 & & & 3 & \\
\hline 7 & 1 & & & 1 & & & & 1 & \\
\hline Total & $\mathbf{4 4}$ & $\mathbf{8}$ & $\mathbf{1}$ & $\mathbf{3}$ & $\mathbf{2 3}$ & $\mathbf{2}$ & $\mathbf{1}$ & $\mathbf{9}$ & $\mathbf{1}$ \\
\hline & $\mathbf{S + 1 A}$ & $\mathbf{S + 2 A}$ & $\mathbf{S + 4 A}$ & $\mathbf{S + 5 A}$ & $\mathbf{1 A + S}$ & $\mathbf{2 A + S}$ & $\mathbf{4 A + S}$ & $\mathbf{1 A + S + 1 A}$ & $\mathbf{1 A + S + 2 A}$ \\
\hline
\end{tabular}




\section{María del Carmen Sala}

\section{Conclusiones}

Aun cuando los críticos han identificado distintas influencias y tendencias en la obra de Abraham Valdelomar, sigue siendo un escritor que desafía las etiquetas. Sus crónicas son muy diversas y en ellas se percibe el desarrollo de un estilo en el que conviven el cosmopolitismo y el arraigo local, la ornamentación poética y la precisión narrativa, la vocación periodística y la literaria.

Como se señaló en el marco teórico, hay quien lo considera esencialmente un poeta y quien lo llama un narrador nato, el verdadero creador del cuento peruano. En las crónicas analizadas se pueden diferenciar las partes donde predomina la descripción - cuando el autor adopta una actitud contemplativa y usa una prosa cargada de ironía o lirismo- de las partes donde prima el relato de los hechos y son evidentes sus habilidades de narrador. Además, se encuentran tanto el humor como la mirada nostálgica; una mirada que podría calificarse con un adjetivo que Valdelomar utiliza, «esplinática». En medio de la diversidad, las cifras permiten formular las siguientes conclusiones:

1. Al narrar, los textos tienen un tono más periodístico y en las descripciones, sobre todo las esplináticas, los adjetivos son más profusos, subjetivos y hasta impertinentes. Sin embargo, no se puede determinar que a las narraciones les corresponde siempre la mayor cantidad de adjetivos objetivos y a las descripciones, la mayor cantidad de adjetivos subjetivos, pues hay narraciones con bajos niveles de adjetivos objetivos y descripciones con pocos adjetivos subjetivos. Lo que sí revelan las cifras es el alto porcentaje de adjetivos y de adjetivos subjetivos incorporados en las crónicas.

2. Con respecto a la estructura, en las cuatro crónicas analizadas se utiliza con mayor frecuencia el sustantivo con un adjetivo pospuesto $(\mathrm{S}+1 \mathrm{~A})$ $y$, en segundo lugar, el sustantivo con un adjetivo antepuesto $(1 A+S)$. La primera estructura se asemeja al lenguaje coloquial y es la que más reproduce la redacción periodística. El segundo esquema se encuentra con mayor frecuencia en los textos literarios.

Ambas conclusiones apuntan a una combinación de los criterios periodísticos y artísticos en la escritura de las crónicas. Valdelomar se asegura de cumplir las exigencias informativas de los medios que publican sus escritos, pero, mientras lo hace, da rienda suelta a su talento.

Valdelomar combina los adjetivos pertinentes, propios de un corresponsal, con los impertinentes que surgen de su percepción artística del mundo (por ejemplo, 
en Desde Roma: cuerpo frío de la manca inconsolable). Pasa con fluidez del relato preciso de los hechos a la descripción reflexiva y emocional, y viceversa. En cada caso, dosifica los adjetivos sin regirse por un único patrón. Los selecciona y distribuye evitando la monotonía: va del minimalismo a la profusión, de la sobriedad intelectual al desborde propio del esteticismo modernista. Y de esa concatenación surge un ritmo que enriquece el texto.

La manera como Abraham Valdelomar usa los adjetivos en sus crónicas es un reflejo de las distintas facetas de un ser humano complejo. Es alguien triste que se ríe, un nihilista que se emociona; aldeano y dandi a la vez.

Se puede intuir una cierta evolución, pues hay diferencias entre la primera (de 1910) y la última crónica (de 1916). En «El rey muerto» predomina la narración, la actitud parece más ingenua y el humor carece de agresividad; solo entonces Valdelomar se burla de sí mismo. La primera hoja seca...” es una crónica introspectiva, en la que se percibe desesperanza y desconfianza y donde los adjetivos subjetivos son más numerosos, pues el foco está colocado en el mundo interior. Entre una y otra, están las otras dos crónicas que están cargadas de desencanto («Desde Roma») y de ironía («Dando el opio»).

El análisis queda inconcuso. Falta ampliar su alcance y explorar otra variable: el objeto de la adjetivación. La simple lectura de las crónicas sugiere que las acciones de las personas generan en Valdelomar escepticismo, decepción y burla, mientras se deja conmover por la naturaleza y los objetos culturales y artísticos. Hacia lo humano dirige una mirada cerebral y crítica. Hacia lo no humano, una mirada cargada de ingenuo deslumbramiento.

Por el momento, es indiscutible que la habilidad en el manejo del lenguaje le permite a Valdelomar adecuar la adjetivación y muchos otros recursos a temas y propósitos variados, abordados mediante la crónica, un género híbrido que se mueve en las fronteras entre periodismo y literatura. Al ejercer un oficio insertado en la maquinaria de la prensa nacional e internacional, se vuelve un precursor de lo que posteriormente se llamaría «nuevo periodismo»o «periodismo literario». Una virtud que se añade a las ya conocidas de este artista aún poco estudiado. 


\section{María del Carmen Sala}

\section{Referencias bibliográficas}

Acuña, M. (2012, mayo 9). Adjetivar cuando es necesario [Blog]. Redactar mejor. Recuperado de http://redactarmejor.blogspot.com/2012/05/adjetivar-cuandoes-necesario.html

Cancio, W. (2010). Crónicas de la impaciencia: el periodismo de Alejo Carpentier. Capítulo I. Los hallazgos de la impaciencia: 1922-1928. Colibrí. Recuperado de https://editorialhypermedia.files.wordpress.com/2014/o2/cronicas-de-la-impaciencia_frag.pdf

Espinoza, E. (2007). La crónica modernista de Abraham Valdelomar (Tesis de maestría). Universidad Nacional Mayor de San Marcos, Lima. http://cybertesis. unmsm.edu.pe/handle/cybertesis/2551.

García-Girón, E. (1959, julio-diciembre). La adjetivación modernista en Rubén Darío. Nueva Revista de Filología Hispánica, 13(3/4). Recuperado de http://www. otroparamo.com/2017/05/02/la-adjetivacion-modernista-en-ruben-dario-2/

Gómez, J. (2001, 8 de agosto). Poniatowska defiende el valor literario de la crónica. El País. Recuperado de https://elpais.com/diario/2001/08/o8/revistaverano/997221602_850215.html

Javaloyes, C. (2011). Uso y abuso de la adjetivación en la literatura. Biblioteca DigitalCiudad Seva. Recuperado dehttps://es.scribd.com/document/51310667/ Uso-y-abuso-de-la-adjetivacion-Carmen-Javaloyes

Lovón, M. (2018). Gallos y adjetivos en El caballero Carmelo. En Marco Martos y Marco Lovón (Eds.), Valdelomar en la letra: Meditaciones (pp. 97-107). Lima: Academia Peruana de la Lengua.

Marcos, A. (2015, 17 de marzo). Cómo empezar a escribir [Video]. Recuperado de http://megustaescribir.com/recurso/162/los-adjetivos-en-la-novela

Matute, A. (1997). Crónica: historia o literatura. Historia mexicana, 46(4), 711-722.

Pérez, R.C. (2017, enero 1). Tres momentos del adjetivo en la poesía modernista: Manuel Gutiérrez Nájera, Rubén Darío y Leopoldo Lugones. Círculo de poesía La Estantería. Recuperado de https://circulodepoesia.com/2017/01/tresmomentos-del-adjetivo-en-la-poesia-modernista/

Ramirez S. (1992, primer semestre) La muerte como motivo en los cuentos de Abraham Valdelomar. Letras, 63(91), 24-42.

Rotker, S. (1992a). Fundación de una escritura: las crónicas de José Martí. La Habana: Ediciones Casa de las Américas.

Rotker, S. (1992b). La invención de la crónica. Buenos Aires: Ediciones Letra Buena. Sánchez, L. (1987). Valdelomar o la «belle époque». Lima: Infopresa. 
Shumway, N. (Marzo, 1992). Hacia el verdadero Mitre: Las ficciones de la historia. Silva Santisteban, R. (2013). Abraham Valdelomar desde la perspectiva del poder. PUCP. Recuperado de http://www.casadelaliteratura.gob.pe/wp-content/ uploads/2013/o9/PONENCIA2.pdf

Tabarovsky, D. (2014, noviembre 29). Crónica: menor es mejor. Informe Escaleno. Recuperado de http://www.informeescaleno.com.ar/index.php?s= articulos\&id $=281$

Valdelomar, A. (1988). Valdelomar. Obras. Lima: Edubanco.

Velázquez, M. (2013, mayo 27). Sucedió en el Perú. Tv Perú [Video]. Recuperado de https://www.youtube.com/watch?v=-Hwvf9AzoEw\&t=29s 